\title{
Keabsahan Tanda Tangan Pada Akta Autentik Secara Elektronik Ditinjau Dari Cyber Notary
}

\author{
Wahyu Tantra Setiadi1, I Nyoman Bagiastra² \\ 1Program Studi Magister Kenotariatan Fakultas Hukum Universitas Udayana, \\ E-mail: wahyu.tantra@rocketmail.com \\ ${ }^{2}$ Fakultas Hukum Universitas Udayana, Email: nyoman_bagiastra@unud.ac.id
}

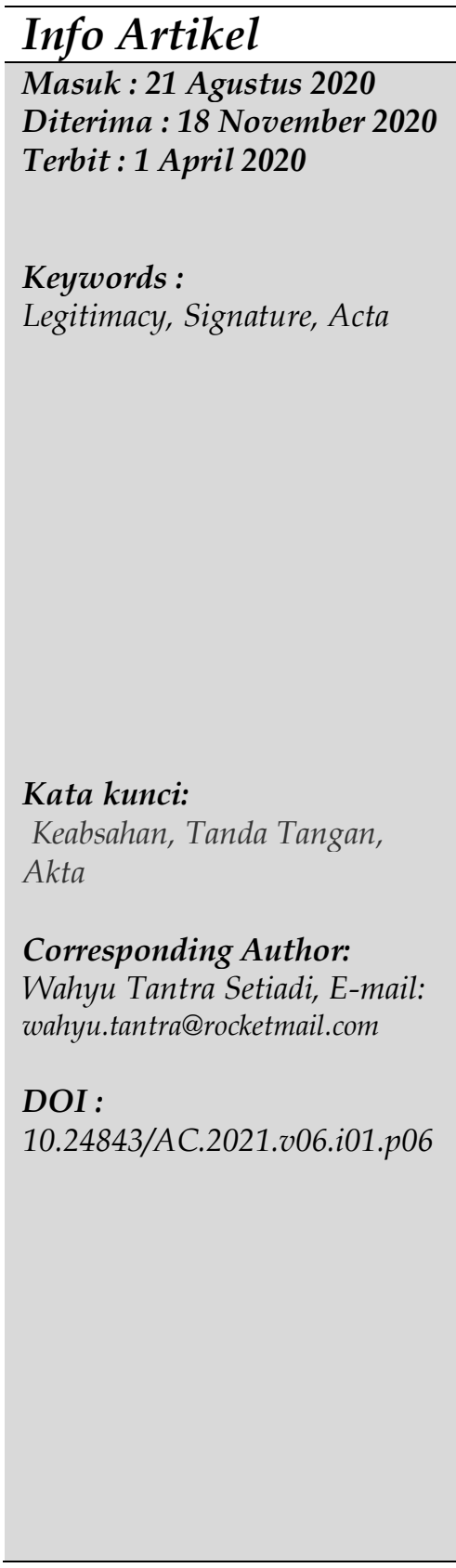

\begin{abstract}
The purpose of this study is to determine and analyze the validity of the signature on authentic deeds which is done electronically. Normative juridical research methods, focusing on the study of legal norms and rules. The results show that (1) PP 82/2012 determines that an electronic signature is a means of authentication and verification. Article 11 of the ITE Law stipulates that electronic signatures are valid if they comply with the law. The UUJN-P has not specifically regulated electronic signatures. (2) The notary's responsibility for electronic signatures has not been regulated normatively, in carrying out his / her position the notary may apply the principle of legal presumption, which has the power of perfect proof as long as no one denies it, if there is falsification of electronic signatures because the notary does not directly see the signing, then proof is borne by the electronic system operator. The conclusion is that electronic signatures have been recognized by law, but the UUJN-P has not specifically regulated them.

\begin{tabular}{l} 
Abstrak \\
\hline Tujuan penelitian ini untuk mengetahui dan menganalisis \\
keabsahan tanda tangan pada akta autentik yang dilakukan \\
secara elektronik. Metode penelitian yuridis normatif, \\
memfokuskan pada kajian norma dan kaidah hukum. Hasil \\
penelitian menunjukkan bahwa (1) Pada PP 82 Tahun 2012 \\
menentukan bahwa tanda tangan secara elektronik sebagai alat \\
autentikasi dan verifikasi. UU ITE Pasal 11 menentukan tanda \\
tangan secara elektronik sah apabila sesuai UU. Dalam UUJN-P \\
belum diatur secara mengkhusus mengenai tanda tangan secara \\
elektronik. (2) Tanggungjawab notaris atas tanda tangan \\
elektronik belum diatur secara normatif, dalam menjalankan \\
jabatannya notaris dapat menerapkan asas praduga sah, yang \\
memiliki kekuatan pembuktian sempurna selama tidak ada yang \\
menyangkalnya, bila ada pemalsuan tanda tangan elektronik \\
dikarenakan notaris tidak melihat secara langsung \\
penandatanganan tersebut maka pembuktian dibebankan pada \\
pihak penyelenggara sistem elektronik. Kesimpulan bahwa tanda \\
tangan secara elektronik telah diakui oleh hukum, namun pada \\
UUJN-P belum mengatur secara khusus.
\end{tabular}
\end{abstract}




\section{Pendahuluan}

Perkembangan zaman di era globaliasi semakin cepat dalam segala bidang, diantaranya teknologi, komunikasi yang sangat sering digunakan oleh setiap orang. Perkembangan teknologi yang kian maju maka teknologi dapat mengatur kebutuhan manusia agar dapat terintegrasi menjadi satu-kesatuan demi memudahkan produktifitas para penggunaannya. Kemajuan tekonologi saat ini memudahkan pengguna untuk melakukan transaksi secara online, yang dapat dilakukan tanpa tidak perlu datang ke tempat penjualan, jadi dimana pun kita berada tetap dapat melakukan transaksi secara elektronik.

Hal tersebut ingin dikembangkan tidak hanya di pasar retail namun bisa hingga ranah administrasi. Pemerintahan telah menggunakan layanan digital yang berbasis online untuk mempercepat dalam memproses birokrasinya agar tidak perlu datang ke kantor untuk membawa berkas-berkas yang banyak lagi, namun tinggal menunggu hingga izin atau surat selesai setelah memasukan data-data yang diperlukan. Sama halnya dengan halnya birokrasi tersebut, dalam menjalankan jabatan notaris adanya pengaturan mengenai cyber notary yang memanfaatkan teknologi untuk memudahkan pekerjaannya.

Kewenangan yang diberikan kepada notaris sebagai pejabat umum berupa kewenangan dalam membuat akta autentik. Selain kewenangan, juga adanya kewajiban serta larangan yang harus ditaati oleh notaris dalam menjalankan jabatannya. Akta autentik yang dibuat seperti berita acara rapat umum pemegang saham, transaksi jual beli, melakukan sewa, perjanjian kredit oleh bank atau finance. Pelaksanaan jabatan notaris diatur dengan dasar hukum yaitu Undang-Undang Nomor 2 Tahun 2014 atas Perubahan Undang-Undang Nomor 30 Tahun 2004 tentang Jabatan Notaris. Pengaturan dalam UUJN-P tersebut, memberikan hambatan dalam pelaksanaan cyber notary. Cyber notary ini muncul berawal karena kebutuhan masyarakat dengan produktifitasnya masing-masing atau mengurus bisnisnya diluar kota bahkan ke luar negeri sekalipun. Konsep ini telah dilakukan beberapa negara di dunia. Pengaturannya di Indonesia masih sangat kurang maka dari itu pada implementasinya belum bisa dijalankan karena kurangnya pengaturan yang jelas mengenai dasar hukum atas tanda tangan elektronik berkaitan dengan cyber notary.

Pengaturan atas kewenangan yang dimiliki notaris pada UUJN-P diatur pada Pasal 15 ayat (3) menentukan bahwa kewenangan notaris diatur pada ayat (1) dan ayat (2), serta kewenangan lainnya diatur dalam undang-undang ini. Dalam bagian penjelasannya pada frasa "kewenangan lain"yang dimaksud adalah kewenangan melakukan sertifikasi pada transaksi elektronik (cyber notary), selain itu dapat pula membuat hipotek atas pesawat terbang dan akta ikrar wakaf. Undang-undang telah memberikan kesempatan untuk menerapkan konsep cyber notary namun hanya secara implisit karena ketentuan tersebut terletak hanya pada penjelasan pasal saja, bukan pada bunyi dari pasal tersebut.

Pengertian secara terbatas dapat dilihat pada penggunaan kata cyber notary dalam tanda baca kurang yang artinya, kata cyber notary merupakan tambahan keterangan 
atau penjelasan dari pada frasa sebelumnya ${ }^{1}$. Walaupun menggunakan teknologi yang tidak mengharuskan para pihak dan atau penghadap untuk hadir secara fisik, tetapi tidak mengurangi kekuatan pembuktian dari akta autentik. Menurut Edmon Makarim, bahwa dalam melakukan transaksi elektronik maka terjadinya pertukaran informasi secara elektronik (digital) kaitannya dengan melakukan suatu perbuatan hukum. Hubungan yang timbul dalam melakukan transaksi elektronik yaitu antara penyelenggara sistem transaksi elektronik dengan kepentingan publik atau secara perdata dengan para pihak dalam melakukan perikatan elektronik. ${ }^{2}$

Kaitannya dengan transaksi elektronik, diatur pada UU ITE. Pada Pasal 5 menentukan informasi atau dokumen elektronik maupun hasil cetaknya merupakan alat bukti yang sah dalam hukum acara, informasi dan/ atau dokumen elektronik serta hasil cetaknya telah diakui sebagai alat bukti hukum yang sah. Hal ini menjadi sejalan dengan cyber notary untuk diterapkan pada profesi notaris, maka notaris bertindak sebagai penyelenggara transaksi elektronik. Pengaturan lebih lanjut mengenai penyelenggara transaksi elektronik, diatur lebih lanjut pada Peraturan Pemerintah Nomor 82 Tahun 2012 Tentang Penyelenggara Sistem Dan Transaksi Elektronik (selanjutnya disebut PP 82 tahun 2012). Pada PP 82 tahun 2012 memberikan pengaturan mengenai notaris sebagai profesi yang diberikan tugas sebagai Lembaga Sertifikasi Keandalan yang bertugas mengeluarkan sertifikat keandalan, bahwa negara memberikan kepercayaan pada profesi notaris sebagai penyelenggara sertifikat keandalan. Pasal 52 menentukan bahwa tanda tangan elektronik memiliki fungsi sebagai alat untuk autentikasi dan verifikasi atas dokumen elektronik yang disepakati serta identitas para pihak yang melakukan tanda tangan secara elektronik sebagai suatu persetujuan. Apabila dalam pelaksanaanya terjadi suatu penyimpangan dalam hal ini penyelahgunaan dari salah satu pihak atas tanda tangan elektronik yang dilakukan, maka perlunya pembuktian yang beban tersebut dibebankan kepada Penyelenggara Sistem Elektronik. Sejauh ini penyelenggara sistem elektronik dipegang oleh pihak pemerintah maupun pihak swasta. Cyber notary merupakan suatu mimpi baru dalam dunia notaris, yang memberikan kemudahan bagi pekerjaan notaris serta menyongsong era digitalisasi dengan menggunakan jaringan internet.

Notaris sebagai pejabat yang ditugaskan untuk membuat alat bukti surat yang secara konvensional harus dibuat dalam bentuk fisik tertulis, perlu adanya perkembangan dengan adanya kewenangan untuk melakukan sertifikasi transaksi elektronik. Keautentikan suatu akta ditentukan dari apakah suatu pelaksanaan sistem transaksi elektronik telah sesuai peraturan perundang-undangan serta dengan menggunakan sistem terkait dengan tanda tangan elektronik melalui sertifikasi. ${ }^{3}$

Sebagaimana kewajiban notaris dalam melaksanakan tugasnya untuk membuat alat bukti yang berupa akta autentik. Kewajiban tersebut meliputi mekanisme pembuatan

1 Putri, C. C., \& Budiono, A. R. (2019). Konseptualisasi dan Peluang Cyber Notary dalam Hukum. Jurnal Ilmiah Pendidikan Pancasila dan Kewarganegaraan, 4(1), h. 33.

2 Makarim, E. (2011). MODERNISASI HUKUM NOTARIS MASA DEPAN: KAJIAN HUKUM TERHADAP KEMUNGKINAN CYBER NOTARY DI INDONESIA. Jurnal Hukum \& Pembangunan, 41(3), h. 476.

${ }^{3}$ Widiasih, N. K. A. E. A Kewenangan Notaris dalam Mensertifikasi Transaksi yang Dilakukan Secara Elektronik (Cyber Notary). Acta Comitas: Jurnal Hukum Kenotariatan, 5(1), h. 156. 
akta, salah satunya yaitu membacakan akta yang telah dibuat notaris yang dihadiri oleh penghadap, dua orang saksi serta setelahnnya harus segera ditanda tangani oleh notaris, penghadap dan saksi-saksi pada Pasal 16 ayat (1) huruf m. Namun pada penjelasan pasal memberikan penekanan lebih khusus bahwa notaris harus ada kehadirannya secara fisik kaitannya dengan pembacaan dan tanda tangan aktanya. Ketentuan ini memberikan hambatan pada penerapan cyber notary. Apabila kewajiban tersebut tidak dijalankan sebagaimana diatur UUJN-P maka kekuatan pembuktian akta autentik menjadi akta dibawah tangan. Apabila dilakukannya tandatangan secara elektronik, asalkan orang yang tertera namanya sebagai penanda tanganan maka tetap memiliki kekuatan hukum yang diatur pada Pasal 11 UU ITE. Adanya kekosongan norma ini, maka penulis tertarik untuk mengangkatnya sebagai penelitian untuk dijadikan karya ilmiah berupa jurnal hukum dengan judul "KEABSAHAN TANDA TANGAN PADA AKTA AUTENTIK SECARA ELEKTRONIK DITINJAU DARI CYBER NOTARY".

Rumusan masalah yang digunakan sesuai dengan uraian diatas, yaitu bagaimana keabsahan tanda tangan pada akta autentik yang dilakukan secara elektronik? dan bagaimana tanggung jawab notaris atas tanda tangan pada akta autentik yang dilakukan secara elektronik kaitannya dengan asas praduga sah? Tujuan dari dilaksanakannya penelitian ini adalah mengembangkan pemahaman dan pemikiran berkaitan dengan bidang hukum pada umumnya dan khususnya untuk konsep cyber notary. Untuk mengetahui dan menganalisis keabsahan tanda tangan pada akta autentik yang dilakukan secara elektronik dan tanggung jawab notaris atas tanda tangan elektronik pada akta autentik berkaitan dengan asas praduga sah. Hal ini menjadi penting dengan tandatangan yang dilakukan secara elektronik agar dapat meningkatkan pelayanan notaris serta dapat lebih memanfaatkan tekonologi yang sudah cukup maju dalam kaitannya cyber notary.

Penulisan ini dibuat dengan menuangkan hasil pemikiran dan orisnalitasnya demi kemajuan dunia ilmu pengetahuan, walaupun ada pembahasan yang menyerupai tulisan lainnya yang lebih dulu ada, namun dalam tulisan ini memiliki unsur pembahasan yang baru. Tulisan ini menggunakan dua tulisan terdahulu menjadi pembandingnya, yaitu :

1. Jurnal yang ditulis oleh Dewa Ayu Wisyda Sari, Universitas Udayana. Judul “Kewenangan Notaris Di Bidang Cyber Notary Berdasarkan Pasal 15 ayat (3) Undang-Undang Nomor 2 Tahun 2014 tentang Perubahan atas Undang-Undang Nomor 30 Tahun 2004 tentang Jabatan Notaris. Rumusan masalah yang diangkat yaitu mengenai bagaimana pembuatan akta oleh notaris atas transaksi elektronik dan apakah notaris berwenang untuk membuat akta atas transaksi elektronik yang dilaksanakan para pihak diluar kedudukan jabatan notaris ${ }^{4}$

2. Jurnal yang ditulis oleh Husnul Hudzaifah, Universitas Tadulako. Judul "Keabsahan Tanda Tangan Elektronik Dalam Pembuktian Hukum Acara Perdata Indonesia". Rumusan masalah yang diangkat yaitu mengena bagaimana keabsahan

\footnotetext{
4 Sari, D. A. W., Murni, R. R., \& Udiana, I. M. (2018). Kewenangan Notaris Di Bidang Cyber Notary Berdasarkan Pasal 15 Ayat (3) Undang-Undang Nomor 2 Tahun 2014 Tentang Perubahan Atas Undang-Undang Nomor 30 Tahun 2004 Tentang Jabatan Notaris. Acta Comitas: Jurnal Hukum Kenotariatan, 2(2).
} 
tanda tangan elektronik dalam pembuktian hukum acara perdata Indonesia dan upaya hukum penyelesaian sengketa perdata terhadap dokumen elektronik yang ditandatangani dengan tanda tangan elektronik ${ }^{5}$

Berdasarkan atas perbandingan kedua penulisan jurnal yang terdahulu terhadap tulisan ini, maka tidak ada upaya untuk meniru dari tulisan yang telah ada terlebih dahulu. Tulisan ini memiliki unsur pembaharuan karena memiliki permasalahan yang berbeda dengan permasalahan pada tulisan-tulisan sebelumnya. Adapun permasalahan yang dibahas yaitu bagaimana keabsahan tanda tangan pada akta autentik yang dilakukan secara elektronik dan bagaimana tanggung jawab notaris atas tanda tangan pada akta autentik yang dilakukan secara elektronik kaitannya dengan asas praduga sah.

\section{Metode Penelitian}

Metode penelitian merupakan suatu cara untuk membantu dalam pemecahan suatu permasalahan yang akan diteliti agar jawabannya menghasilkan kajian ilmiah. Penelitian pada penulisan ini menggunakan penelitian hukum normatif. Merupakan suatu penelitian yang mengkaji peraturan perundang-undangan yang berkaitan dengan topik pembahasan dengan teteap memperhatikan heirarki dari peraturan itu sendiri. Penelitian ini beranjak dari adanya kekosongan normal, dikarenakan tidak adanya pengaturan tanda tangan elektronik pada akta autentik berkaitan dengan cyber notary. Penelitian ini menggunakan pendekatan perundang-undangan dan pendekatan konseptual. ${ }^{6}$ Teknik studi pustaka yang menggunakan bahan hukum primer seperti peraturan-peraturan yang terkait dengan topik yang dibahas, bahan hukum sekunder seperti buku-buku, karya tulis hukum, dan bahan hukum tersier seperti internet, kamus besar bahasa indonesia. Setelah terkumpulnya bahan-bahan tersebut maka dianalisis dengan menggunakan teknik analisis deskriptif dan secara sistematis.

\section{Hasil Dan Pembahasan}

\subsection{Keabsahan Tanda Tangan Pada Akta Autentik Yang Dilakukan Secara Elektronik}

Mengenai kewajiban notaris sebagaimana diatur dalam Pasal 16 UUJN-P, ayat (1) huruf $\mathrm{m}$ menentukan bahwa notaris dalam membuat akta harus membacakan akta tersebut dihadapan para penghadap dengan dihadiri oleh saksi-saksi, lalu setelahnya harus segera ditandatangani oleh penghadap, saksi-saksi dan notaris. Kembali ditegaskan pada penjelasan pasalnya yaitu notaris diharuskan kehadirannya secara fisik dalam menandatangani aktanya dihadapan penghadap dan saksi-saksi. Penerapan cyber notary dilakukan tanpa berhadapan langsung secara fisik oleh notaris dengan penghadap. Adanya pengaturan yang secara implisit memberikan peluang dalam pelaksanaan cyber notary pada penjelasan Pasal 15 ayat (3) menentukan notaris memiliki kewenangan lain seperti melakukan sertifikasi terhadap transaksi elektronik (cyber notary). Pasal ini sebenarnya memberikan peluang pada notaris dalam melakukan penerapan cyber notary. Notaris memiliki kesempatan untuk melakukan

\footnotetext{
${ }^{5}$ Hudzaifah, H. (2015). Keabsahan Tanda Tangan Elektronik Dalam Pembuktian Hukum Acara Perdata Indonesia. Katalogis, 3(5).

6 Marzuki, P. M. (2010). Penelitian Hukum Normatif, Jakarta: Kencana Prenada Media Group., h. 93.
} 
autentifikasi dokumen secara elektronik, bahwa mengautentifikasi dokumen dilakukan dengan cara melakukan print out dimanapun dan kapan pun saat diperlukan.

Adanya perkembangan teknologi yang sangat maju ini, memberikan kemudahan dalam melakukan pekerjaan notaris serta meningkatnya kinerjanya dengan menerapkan cyber notary dengan tetap memberikan kepastian hukum pada pihak yang sedang berada diluar negeri dan tetap dapat melakukan penanda tanganan pada suatu akta autentik secara elektronik yang dilakukan dengan keadaan sadar dan tanpa tekanan dari mana pun yang dibuat oleh notaris.

Notaris diberikan sebagian kewenangan oleh negara dalam bidang hukum privat untuk membuat alat bukti surat (akta autentik) untuk memberikan kepastian hukum bagi setiap masyarakat yang akan melakukan suatu perbuatan hukum. ${ }^{7}$ Dalam membuat akta autentik, akta tersebut terbagi atas akta relaas dan akta partij. ${ }^{8}$ Pasal 1868 KUHPer menentukan akta dibuat dihadapan dan/ atau oleh pejabat umum yang berwenang sebagaimana bentuknya telah ditetapkan undang-undang. Dengan pengertian tersebut dapat diartikan bahwa dihadapan dapat saja dilakukan secara virtual, karena virtual dapat saling berhadapan dengan melihat pada kamera yang digunakan pada masing-masing perangkat elektronik. Hal tersebut dianggap memberikan peluang untuk menerapkan cyber notary.

Tanda tangan secara elektronik telah memiliki pengaturan dalam UU ITE. Tanda tangan elektronik sebenarnya sama dengan tanda tangan manual yang secara umum sangat sering digunakan. Hadirnya tanda tangan elektronik memberikan kemudahan bagi para pihak untuk melakukan suatu persetujuan serta untuk memanfaatkan teknologi yang telah kaitannya menuju era digital atau yang sering disebut industri 4.0. Tanda tangan elektronik sebagaimana Pasal 1 angka 12 merupakan tanda tangan yang terkait dengan informasi dan dokumen elektronik yang telah didaftarkan pada penyelenggaran sistem elektronik (pihak ketiga) berfungsi juga untuk autentikasi dan verifikasinya. Walaupun dalam bentuk digital tanda tangan ini juga memiliki kepastian dan akibat hukum bagi para pihak yang melakukannya. Untuk mendukung pelaksanaannya maka perlu memenuhi beberapa persyaratan agar suatu tanda tangan elektronik dapat dikatakan sah, diatur pada Pasal 11 ayat (1) yaitu a. pembuatan data terlebih dahulu dari pihak yang akan melakukan tanda tangan elektronik; b. proses penandatanganan hanya boleh pada kuasa pihak yang terdaftar; c. apabila terjadi perubahan setelah dilaksanakannya tanda tangan, maka perubahan dapat segera diketahui. Adanya tanda tangan elektronik tersebut tidak mengurangi dari makna serta kepastian hukum yang ditimbulkan dikemudian hari. Tanda tangan elektronik memiliki akibat hukum yang sama dengan tanda tangan manual, hanya saja tanda tangan elektronik diterapkan dengan menggunakan teknologi yang telah maju untuk memberikan kemudahan untuk melakukan persetujuan walaupun tidak bertemu

7 Alwajdi, M. F. (2020). Urgensi Pengaturan Cyber Notary Dalam Mendukung Kemudahan Berusaha Di Indonesia. Jurnal Rechts Vinding: Media Pembinaan Hukum Nasional, 9(2), h. 267.

8 Wijaya, P. A. P. D. (2018). Tanggung Jawab Notaris Terhadap Kesalahan Dalam Pembuatan Akta Yang Dilakukan Oleh Notaris Penggantinya. Jurnal Hukum Bisnis, 2(2), h. 36. 
secara langsung. Hanya saja tanda tangan elektronik mendapatkan kode unik sebagai kunci privat yang dimiliki oleh para pihak, sebagai proses autentikasi dan verifikasi

Adanya pembatasan yang diberikan pada UU ITE yang tidak memperbolehkan dibuat secara elektronik bila surat/dokumen yang diharuskan dibuat dalam bentuk tertulis dan ataupun dalam akta notariil. Hal ini semakin diperkuat pada UUJN-P yang mengatur mengenai notaris harus hadir secara fisik dalam melakukan pembacaan akta maupun untuk menandatangani akta. Peraturan pelaksanaan tanda tangan elektronik diatur dalam PP 82 Tahun 2012. Bahwa tanda tangan elektronik adalah tanda tangan yang terdiri atas informasi elektronik pihak yang melakukan tanda tangan serta sebagai alat untuk melakukan autentikasi dan verifikasi sebagaimana diatur pada Pasal 1 angka 19. Pasal 54 menentukan mengenai tanda tangan yang tersertifikasi dan tanda tangan tidak tersertifikasi. Adapun perbedaan yang terjadi antara kedua jenis tanda tangan elektronik tersebut, bahwa tanda tangan tersertifikasi dibuat dengan menggunakan pihak ketiga (penyelenggara sertifikasi elektronik) serta memiliki kekuatan pembuktian dengan sertifikat elektronik yang dikeluarkan dari pihak penyelenggara sebagai bukti yang sah. Tanda tangan tidak tersertifikasi maka dilakukan tanpa menggunakan pihak ketiga dan tidak mendapatkan buktinya berupa sertifikat elektronik karena tidak menggunakan jasa dari penyelenggara sertifikasi elektronik.

Untuk membuat tanda tangan elektronik yang tersertifikasi, perlu beberapa tahapan yang dilakukan untuk penggunanaannya yaitu tahap pertama pihak yang ingin menggunakan tanda tangan elektronik perlu mendaftarkan data diri terlebih dahulu kepada pihak ketiga serta dengan dokumen dan tanda tangan elektroniknya. Lalu pihak ketiga mengirimkan dokumen yang harus ditanda tangani kepada pihak lain agar dapat ditanda tangani serta pada saat itu juga mengisikan data diri sebagai alat verifikasi dari data diri dan tanda tangan yang telah didaftarkan sebelumnya. Dalam proses autentikasi, pembentukan suatu tanda tangan elektronik didukung dengan sidik jari sebagai autentikasi pada dokumen yang dibuatnya dan mendapatkan kunci privat sebagai satu kesatuan dalam proses autentikasi dan verfikasi yang akan mereferensikan kepada dokumen asli yang akan dilakukan penandatanganan. Apabila tahapan verifikasi dan autentikasi telah dilaksanakan maka dapat mengetahui apakah dokumen yang dibuat serta akan ditandatangani sesuai dengan kunci privat yang dimiliki. Bila setelah tanda tangan elektronik telah dilakukan, dan ingin melakukan perubahan maka harus dilaporkan terlebih dahuku kepada pihak ketiga. Jadi hal ini dapat mencegah kecurangan dari para pihak apabila ingin memalsukan dokumen atau tanda tangan elektronik.

Apabila dalam melakukan kedua tahapan tersebut dapat dipenuhi, maka suatu tanda tangan elektronik memenuhi unsur yuridisnya dengan demikan memiliki kepastian hukum yang sebagaimana seperti tanda tangan manual yang dilakukan secara konvensional. Seseorang yang telah melakukan penandatanganan secara elektronik berarti dianggap telah memahami dan mengakui mengenai tulisan yang terdapat dalam dokumen elektronik yang bersangkutan. Bahwa tanda tangan elektronik bersifat "one signature document" artinya tanda tangan elektronik yang digunakan pada suatu dokumen maka hal tersebut selalu melekat, dan jika terjadi perubahan maka tanda tangan tangan dan dokumen yang digunakan tidak akan valid dalam melakukan proses verfikasi. Layanan Sertifikasi (certification) yaitu suatu layanan yang 
diberikan untuk membuktikan identitas dari dokumen elektronik tersebut. ${ }^{9}$ Dalam melakukan proses autentikasi dan verifikasi dapat dilakukan pada website Kementerian Komunikasi dan Informati (selanjutnya disebut Kominfo) https://tte.kominfo.go.id/verifyPDF atau pada penyelenggara sertifikasi elektronik seperti Perum Peruri, PrivyID, Vida, Digisign.

Tujuan dari digagasnya cyber notary yaitu untuk memberikan kewenangan kepada notaris dalam melakukan sertifikasi dan autentiksi dalam kegiatan transaksi elektronik. Kewenangan mensertifikasi tranksasi elektronik diatur dalam penjelasan pasal, yang dalam hal ini diberikan secara implisit dikarenakan tercantum bukan pada bunyi pasalnya melainkan pada penjelasan pasal sebagaimana tercantum Pasal 15 ayat (3). Namun ketentuan pada PP 82 Tahun 2012 yang memberikan kewenangan pada notaris dapat membentuk lembaga sertifikasi keandalan profesional yang diatur pada Pasal 69. Bahwa dalam mensertifikasi transaksi elektronik dari notaris yang memiliki artinya notaris dapat mengeluarkan sertifikat digital (digital certificate) sebagai alat bukti telah disertifkasi suatu transaksi elektronik kepada pihak yang berkepentingan. Namun berbeda dengan fungsi dari autentikasi yang memiliki kaitan dengan aspek hukum yang merupakan bagian yang harus dilaksanakan dan dipenuhi dalam melaksanakan suatu transaksi elektronik. ${ }^{10}$

Jadi dengan pengaturan mengenai tanda tangan secara elektronik yang diatur dalam UU ITE dan PP 82 Tahun 2012 yang menjadi dasar hukum. Hanya saja UUJN-P belum memiliki pengaturan yang jelas mengatur mengenai penerapan tanda tangan elektronik untuk memberikan kemudahan bagi para penghadap maupun notaris dalam melakukan tanda tangan pada akta secara elektronik, tanpa perlu melakukan pertemuan secara fisik, melainkan hanya dengan mengirimkan dokumen secara elektronik maka dapat langsung ditanda tangani secara elektronik juga. Namun adanya ketentuan lainnya dalam UU ITE pada Pasal 5 ayat 4 menentukan pada transaksi elektronik tidak berlaku pada surat yang harus dibuat dalam bentuk tertulis dan pada akta notariil. Namun tidak memberikan pembatasan dalam hal tandatangan elektronik pada akta notaris secara elektronik. Pada dasarnya akta dibuat tidak ditulis tangan secara manual, melainkan diketik pada komputer dalam bentuk digital. Notaris juga akan melakukan print out atas akta yang dibuat secara digital, sebagai alat bukti fisik serta dalam UUJN-P mengharuskan notaris untuk menyimpan minuta aktanya sebagai protokol notaris hingga jabatannya selesai dan dialihkan kepada notaris penggantinya. Akta notaris dapat dikatakan tidak ideal jika melanggar ketentuanketentuan sebagaimana diatur dalam UUJN-P dan dapat dibuktikan keabsahannya baik dari aspek lahiriah, materiil dan formil.11

\footnotetext{
${ }^{9}$ Nurita, E. (2012). Cyber Notary. Pemahaman Awal dalam Konsep Pemikiran, Refika Aditama, Bandung, h. 4.

${ }^{10}$ Matra, A. F. (2012). Penerapan Cyber Notary di Indonesia Ditinjau dari Undang-undang Nomor 30 Tahun 2004 tentang Jabatan Notaris (Doctoral dissertation, Tesis, Depok), h. 58.

11 Rifa'i, A., \& Iftitah, A. (2018). BENTUK-BENTUK PELANGGARAN HUKUM DALAM PELAKSANAAN JABATAN NOTARIS. Jurnal Supremasi, 8(2), 4-4, h. 47.
} 


\subsection{Tanggung Jawab Notaris Atas Tanda Tangan Pada Akta Autentik Yang Dilakukan Secara Elektronik Kaitannya Dengan Asas Praduga Sah.}

Pembuatan akta sebagaimana diatur dalam UUJN-P mengenai bentuk akta dalam Pasal 38. Pengertian lebih lanjut tentang sertifikasi tidak dijabarkan lebih lanjut pada UUJN-P, sedangkan menurut Emma Nurita pengertian sertifikasi itu sendiri adalah memberikan suatu penetapan yang dilakukan oleh pihak ketiga yang profesional yang telah melewati suatu proses kelayakan. ${ }^{12}$ Kaitannya dengan melakukan sertifikasi pada tanda tangan elektronik yang diatur Pasal 11 UU ITE yang memberikan kepastian hukum dan akibat hukum apabila tanda tangan elektronik memenuhi persyaratan. Tanda tangan memiliki arti persetujuan antara pihak yang bersepakat atas suatu hal.

Namun adanya hambatan mengenai penerapan tanda tangan elektronik, karena pada penjelasan Pasal 16 ayat (1) huruf m menentukan bahwa notaris, penghadap dan saksi diharuskan kehadiran secara fisik pada pembacaan dan tanda tangan akta. Ketentuan ini menghalangi penerapan cyber notary dalam penggunaan teknologi yang seharusnya dapat memberikan kemudahan bagi notaris serta para pihak dalam melakukan pembacaan dan tandatangan pada akta. Jika diartikan secara fisik, dapat pula dengan menggunakan video conference yang juga sebagai hadir secara fisik dengan tatap muka secara langsung secara virtual. Yang dimana pada akta RUPS juga menggunakan video conference serta tanda tangan elektronik yang sebagaimana telah diatur pada Pasal 77 Undang-Undang Nomor 40 Tahun 2007 tentang Perseroan Terbatas (UU PT).

Pembuatan akta dengan cyber notary terjadi pada saat dilangsungkannya video conference, yang didahului dengan penyampaian maksud dan tujuan akan membuat akta berkaitan dengan perbuatan hukum yang akan dilakukan, menunjukan identitas para pihak melalui video conference yang sedang berlangsung serta mengirimkan identitas dalam bentuk softcopy berupa surel guna mencocokan indentitas yang telah ditunjukan oleh para pihak kepada notaris untuk dilanjutkan pada pembuatan akta hingga pada pembacaan isi akta dihadapan para pihak dan saksi-saksi setelah itu dilanjutkan dengan penandatanganan secara elektronik. ${ }^{13}$

Melaksanakan tanda tangan elektronik terbagi atas dua jenis sebagaimana diatur pada Pasal 54 UU ITE menentukan mengenai tanda tangan tersertifikasi dan tanda tangan tangan tidak tersertifikasi. Apabila menggunakan tanda tangan tersertifikasi maka memerlukan pihak penyelenggara yaitu pihak ketiga sebagai Certification Authority (CA) yang bertugas untuk mengauntetikasi dan memverifikasi serta memberikan jaminan kepastian pada suatu tanda tangan. Menggunakan tanda tangan tidak tersertifikasi maka tidak memerlukan pihak penyelenggara. Adapun beberapa penyelenggara sistem elektronik yang ada di Indonesia dari sisi pemerintah seperti Badan Pengkajian dan Penerapan Teknologi dan Balai Sertifikasi Elektronik Badan Siber dan Sandi Negara, serta dari korporasi seperti Perum Peruri, PrivyID, Vida, Digisign. ${ }^{14}$ Penyelenggara sistem elektronik ini dapat memudahkan pelaksanaan dalam melakukan tanda tangan elektronik. Kepedulian pemerintah akan kemajuan

\footnotetext{
12 Nurita, E., Op.Cit, h. 27

${ }^{13}$ Rossalina, Z. (2016). Keabsahan Akta Notaris Yang Menggunakan Cyber Notary Sebagai Akta

Otentik. Kumpulan Jurnal Mahasiswa Fakultas Hukum., h. 18.

14 https://tte.kominfo.go.id/listPSrE/__ diakses tanggal 10 Juli 2020.
} 
teknologi ini, dimanfaatkan sangat baik agar dapat memberikan kemudahan pada pelayanan-pelayanan yang dibutuhkan oleh masyarakat.

Kaitannya dengan asas praduga sah, bahwa akta notaris akan selalu dianggap sah dan sempurna dalam nilai pembuktiannya sebelum adanya pihak yang menyangkalnya di muka pengadilan. Apabila ada penghadap yang dari awal telah memiliki itikad buruk untuk membuat akta autentik dihadapan notaris dengan memberikan keterangan dan dokumen palsu yang dimana notaris sendiri tidak mengetahuinya. Terbitnya akta tersebut menimbulkan hak dan kewajiban diantara para pihak dan hingga akibat hukum yang dapat timbul dikemudian hari dari akta autentik itu akan selalalu mengikat dan dianggap sah kecuali ada yang menyangkalnya. Sebagaimana pun juga notaris dalam membuat akta autentik harus tetap mengikuti aturan yang sudah ada, seperti dalam UUJN-P Pasal 15, Pasal 16, Pasal 17, Pasal 38 dan selama perbuatan tersebut sesuai maka notaris dapat dibenarkan dalam kaitannya dengan asas praduga sah saat menjalankan jabatannya. Bila dalam pembuatan akta tersebut adanya penyimpangan-penyimpangan yang dilakukan notaris dalam kedudukannya membuat akta autentik, dikarenakan belum ada pengaturan yang jelas tentang tanda tangan elektronik yang diatur secara khusus pada jabatan notaris maka dapat dikenakan sanksi administratif pada Pasal 85 UUJN, secara perdata dikaitkan dengan Pasal 1365 yaitu perbuatan melawan hukum, apabila para pihak yang merasa dirugikan akibat dilakukannya tanda tangan elektronik dapat membuktikan sebaliknya dari isi akta tersebut. Adapun beberapa konsekuensinya yang dapat timbul bila akta tidak sesuai ketentuan yaitu :15 akta dapat dibatalkan, akta batal demi hukum, akta dibatalkan karena adanya putusan pengadilan yang memiliki kekuatan hukum tetap.

Jadi diperlukan adanya pembaharuan terhadap UUJN-P yang berkaitan mengenai pelaksanaan pembuatan akta, tanda tangan dan yang berkaitan mengenai cyber notary. Selain itu diperlukannya pengertian dan pendefinisian yang lebih spesifik pada kewenangan notaris dalam melakukan sertifikasi yang menggunakan konsep cyber notary baik dalam pembuatan akta, pengesahan akta, dan melakukan tanda tangan elektronik. Terobosan ini yang telah digunakan beberapa negara dan sekarang akan diterapkan di Indonesia merupakan suatu langkah yang baik, karena sudah seharusnya Indonesia memanfaatkan tekonologi yang sudah kian maju agar dapat semakin berguna terutaman untuk memberikan pelayanan maksimal oleh notaris. Edmon Makarin berpendapat dalam menjalankan jabatan notaris yang harus ada kehadiran secara fisik merupakan suatu perdebatan yang berkepanjangan, padahal dengan melakukan video conference merupakan suatu pertemuan yang dapat diartikan secara fisik karena dapat melihat secara langsung. Bahwa pemerintah telah mendukung dengan memberikan pengaturan mengenai pelaksanaan penyelenggara sistem transaksi elektronik PP 82 Tahun 2012 dan pada UU ITE. Tanggung jawab notaris sebatas pembuatan akta yang dibuatnya, karena notaris dalam menjalankan jabatannya tidak boleh turut serta dalam kesepakatan para pihak atas isi akta. Serta notaris juga memiliki asas praduga sah, bahwa akta yang dibuatnya adalah benar sebagaiaman yang diinginkan oleh para pihak dan sebenar-benarnya tertuang dalam akta tersebut.

${ }^{15}$ Adjie, H. (2011). Kebatalan dan Pembatalan Akta Notaris. Refika Aditama, h.81. 


\section{Kesimpulan}

Berdasarkan uraian dari pembahasan diatas, maka dapat disimpulkan sebagai berikut : Keabsahan tanda tangan elektronik merupakan penerapan dari ketentuan pada UU ITE dengan PP 82 Tahun 2012, sedangkan dalam UUJN-P belum memberikan pengaturan yang spesifik terkait dengan tanda tangan elektronik pada akta autentik, hanya saja Pasal 15 ayat (3) memberikan kewenangan untuk melakukan sertifikasi transaksi elektronik (cyber notary) yang definisinya belum diatur lebih lanjut dalam UUJN-P. Tanggung jawab notaris atas keabsahan tanda tangan yang dilakukan secara elektronik belum diatur secara normatif. Untuk itu asas praduga sah notaris tetap berlaku sebagaimana akta yang dibuat notaris tetap dianggap sah selama tidak ada yang membuktikan sebaliknya. Untuk menunjang pelaksanaan tanda tangan elektronik, diharapkan menggunakan penyelenggara sistem elektronik yang ada di Indonesia seperti Badan Pengkajian dan Penerapan Teknologi dan Balai Sertifikasi Elektronik Badan Siber dan Sandi Negara, Perum Peruri, PrivyID, Vida, Digisign. Agar beban pembuktian atas kebenaran tanda tangan elektronik bila adanya pemalsuan atau gugatan ditujukan kepada penyelenggara (pihak ketiga).

\section{Daftar Pustaka/Daftar Referensi}

\section{Buku}

Adjie, H. (2011). Kebatalan dan Pembatalan Akta Notaris. Refika Aditama.

Marzuki, P. M. (2010). Penelitian Hukum Normatif, Jakarta: Kencana Prenada Media Group.

Nurita, E. (2012). Cyber Notary. Pemahaman Awal dalam Konsep Pemikiran, Refika Aditama, Bandung.

\section{Jurnal}

Alwajdi, M. F. (2020). Urgensi Pengaturan Cyber Notary Dalam Mendukung Kemudahan Berusaha Di Indonesia. Jurnal Rechts Vinding: Media Pembinaan Hukum Nasional, 9(2).

Hudzaifah, H. (2015). Keabsahan Tanda Tangan Elektronik Dalam Pembuktian Hukum Acara Perdata Indonesia. Katalogis, 3(5).

Makarim, E. (2011). MODERNISASI HUKUM NOTARIS MASA DEPAN: KAJIAN HUKUM TERHADAP KEMUNGKINAN CYBER NOTARY DI INDONESIA. Jurnal Hukum \& Pembangunan, 41(3).

Putri, C. C., \& Budiono, A. R. (2019). Konseptualisasi dan Peluang Cyber Notary dalam Hukum. Jurnal Ilmiah Pendidikan Pancasila dan Kewarganegaraan, 4(1).

Rifa'i, A., \& Iftitah, A., 2018, Pelanggaran Dalam Pelaksanaan Pada Jabatan Notaris, Jurnal Supremasi, 8(2).

Rossalina, Z. (2016). Keabsahan Akta Notaris Yang Menggunakan Cyber Notary Sebagai Akta Otentik. Kumpulan Jurnal Mahasiswa Fakultas Hukum. 
Sari, D. A. W., Murni, R. R., \& Udiana, I. M. (2018). Kewenangan Notaris Di Bidang Cyber Notary Berdasarkan Pasal 15 Ayat (3) Undang-Undang Nomor 2 Tahun 2014 Tentang Perubahan Atas Undang-Undang Nomor 30 Tahun 2004 Tentang Jabatan Notaris. Acta Comitas: Jurnal Hukum Kenotariatan, 2(2).

Widiasih, N. K. A. E. A Kewenangan Notaris dalam Mensertifikasi Transaksi yang Dilakukan Secara Elektronik (Cyber Notary). Acta Comitas: Jurnal Hukum Kenotariatan, 5(1).

Wijaya, P. A. P. D. (2018). Tanggung Jawab Notaris Terhadap Kesalahan Dalam Pembuatan Akta Yang Dilakukan Oleh Notaris Penggantinya. Jurnal Hukum Bisnis, 2(2).

\section{Tesis}

Matra, A. F. (2012). Penerapan Cyber Notary di Indonesia Ditinjau dari UndangUndang Nomor 30 Tahun 2004 tentang Jabatan Notaris (Doctoral dissertation, Tesis, Depok).

\section{Peraturan Perundang-Undangan}

Undang-Undang Nomor 40 Tahun 2007 Tentang Perseroan Terbatas

Undang-Undang Nomor 11 Tahun 2008 Tentang Informasi Transaksi Elektronik

Undang-Undang Nomor 2 Tahun 2014 Tentang Perubahan Atas Undang-Undang Nomor 30 Tahun 2004 Tentang Jabatan Notaris

Peraturan Pemerintah Nomor 82 Tahun 2012 tentang Penyelenggaraan Sitem Dan Transaksi Elektronik

\section{Internet}

https://tte.kominfo.go.id/listPSrE/_diakses tanggal 10 Juli 2020. 